\title{
To Study the Economic Viability of Different Farming System in Bhind District of Madhya Pradesh, India
}

\author{
D. S. Suman ${ }^{1 *}$, G. Bihare ${ }^{2}$, G. S. Patel ${ }^{2}$, P. K. Patel ${ }^{2}$ and J. S. Raghywanshi ${ }^{1}$ \\ ${ }^{1}$ Department of Agriculture Economics, ${ }^{2}$ Department of Agriculture Extension Education, \\ Rajmata Vijayaraje Scindia Krishi Vishwa Vidyalaya,Gwalior, 474002, India, \\ ${ }^{1}$ Department Agriculture Economics RVSKVV Gwalior, 4742002, India \\ *Corresponding author
}

\section{A B S T R A C T}

\section{Keywords}

Farming system,

Economic viability, Rainfed farming, irrigated farming, Diversification index

Article Info

Accepted:

18 May 2020

Available Online:

10 June 2020
The study was conducted in Bhind district of Madhya Pradesh, the objectives of this research are to study the economic viability of different farming system and to identify the constraints in adoption of improved production practices in different farming system. The finding of the research revealed that When comparing the difference between net income realized under rainfed farming system and irrigated farming system, the net income of Rs.686 was realized in irrigated system over rainfed farming system. Irrigated farming system apart from bajra, wheat and gram are provided byproduct as an animal fodder. These by-products realized an extra net income of Rs.4205 per unit area. the data that among two combinations i.e. rainfed farming system (crop production +2 milch animals) and irrigated farming system (crop production +2 milch animals), Farming system II gave higher net income in respect of increase total return over enterprise and feed and fodder for milch animal and additional employment for family labour. Hence, it implies (crop production +2 milch animals) in irrigated situation was the best crop and livestock combination for favourable income and enterprise.

\section{Introduction}

Agriculture is a sort of replacement of nature's favourite plants by cultivation of man's choice, and hence, it is sort of man's imposition on nature and a constant battle against it. Farmers have to work continuously in association with nature and use of the role more and more in relation to other factors of production. Agricultural activities are, therefore, indirectly influenced by the geographical environment, and the part played by nature being more prominent in agriculture than in any occupation. In India as well as in Madhya Pradesh also agriculture presents a close combination of a business and a way of life.

Farming is an income and employment generating activity. Many progressive farmers have learned the art of allocating their scarce resources to alternative uses and sustain 
themselves on a self-supporting agrarian system. Diversified Farming is one in which farmers are helped to make optimum use of their labour, capital, equipment's and land and this makes it a full year's enterprise. As such, central to the classification of farming is the farmer himself who works under natural and socio-economic environments. Many types of farming are done by the farmers based on their choice and available resources. Among this mixed farming is the most relevant system of farming in Indian conditions, because of small size of holdings and unsound economic state of the average Indian farmer. Generally, under mixed farming crop production is combined with animal production. Livestock enterprise is complementary to crop production and viceversa, depending on the relative emphasis given to one or the other.

\section{Materials and Methods}

The present study was carried out in Bhind district of Madhya Pradesh. Bhind district was selected purposively as it is one of the major mixed farming areas which consisted of both irrigated and unirrigated cropping system with livestock production. Bhind district has 7 blocks and among them, at first stage "Mehgaon" block was selected on the basis of higher concentration of livestock population with rainfed farming system and irrigated farming system. a list of villages was prepared with the help of Department of Veterinary Center, where cattle rearing is a common practice and rainfed farming as well as irrigated farming system are found to in practice. Among this list five villages were selected on the basis of highest number of milch cattle available in the village. A list of farmers of each village was prepared who are adopting the mixed farming system on their farm with rainfed and irrigated farming system. In the final stage of sampling 25 farmers were randomly selected from each category. Thus, the total 75 farmers were treated as respondents of the study. Primary data was collected from sample farmers. The primary data was recorded regarding general information of the respondents, cropping pattern, farm resource structure. The data were collected using survey method. The data on different aspects were collected through pre-tested interview schedule. Each selected sample farmers were approached personally for recording of relevant data.

\section{Results and Discussion}

\section{Economic viability of different farming system}

Mixed farming system (crop + livestock units) in rainfed and irrigated conditions involve ruminating animals become complementary to the plant-man food systems. Today mixed farming system involving raring of few animals with crop production which are become more relevant. Table 1 presented the economics (economic viability) of different mixed farming modules suitable for sample farmers in study area. Farming system is aimed at the efficient use of resources to maximize the income. It also minimizes the production risk by spreading the risk to various enterprises instead of one activity. It is evident from data that crop production (bajra followed by wheat and gram) +2 milch animals i.e. irrigated farming system was the most suitable in respect of higher average net income per unit area Rs.84006 per year, while, rainfed farming system (bajra followed by mustard +2 milch animals) provides Rs.83380 per unit area per year. When comparing the difference between net income realized under rainfed farming system and irrigated farming system, the net income of Rs.686 was realized in irrigated system over rainfed farming system. The size of group showed no any specific trend in respect of net return from crop + livestock 
system in this module. The highest net income from this module was incurred Rs.86247 with B.C. ratio of 2.39 in medium farmer and minimum was incurred Rs.80869 with B.C. ratio 2.24 in case of large farmer. This shows that livestock production with crop enterprise is very much suitable for smaller size of holding in respect of total net return per year. Since, crop + livestock unit provide additional income and employment to rural people with food and manure for agriculture. In rural area, cattle are fed on crop residues like straw, supplemented with a small amount of green forage and fodders crops etc. Hence, in rural area crop + livestock have been given considerable importance as a complimentary and supplementary instrument for social and economic change. In this respect, in irrigated farming system apart from bajra, wheat and gram are provided by-product as a animal fodder. These by-products realized an extra net income of Rs.4205 per unit area.

Thus, it can be concluded from the data that among two combinations i.e. rainfed farming system (crop production +2 milch animals) and irrigated farming system (crop production +2 milch animals), Farming system II gave higher net income in respect of increase total return over enterprise and feed and fodder for milch animal and additional employment for family labour. Hence, it implies (crop production +2 milch animals) in irrigated situation was the best crop and livestock combination for favourable income and enterprise. The diversification index for both the farming system was carried out to determine the importance of livestock system in different farming system. The diversification index for farming system for different size of holding and for all farms as a whole clearly indicates that crop + livestock system found to suitable among both the rainfed and irrigated farming system because diversification index for both the farming system found to less than one. This low and approximate similar diversification index shows that no farming system can be shifted in each other because there is no any chance of increasing the irrigation facilities in study area.

\section{Identification of constraints in adoption of improved production practices in different farming system}

The constraints associated with different farming systems in study area of selected district are presented in table 2. The sampled farmers are grouped as per frequency i.e. higher than average and lower to average number. In the study area higher percentage of sample respondents opined that "low price for the produce" were measure constraints reported by 82.67 per cent followed by "high cost of inputs and improved technology" reported by $(80.00 \%)$, "unavailability of marketing loan" reported by $(76.00 \%)$, "uncertain of rainfall" reported by $(74.67 \%)$, "shortage of labour at peak period" reported by $(73.33 \%)$, "scarcity of owned funds" reported by $(65.33 \%)$ and "high infestation of disease and pest" reported by $(56.00 \%)$ respectively. On the other hand, the respondents who have got lower frequency than average number (low level of constraints) opinioned that "lack of timely supply of inputs" is the main constraints reported by $(49.33 \%)$ followed by "unfavourable climatic condition" reported by (48.00\%), "lack of knowledge improved technology" reported by $(40.00 \%)$, "high transportation charges" reported by $(36.00 \%)$, "lack of credit availability" reported by (34.67\%), "lack of proper management of family labour" reported by (33.33\%), "lack of proper marketing system" reported by $(32.00 \%)$, "lack of storage facility" reported by $(30.67 \%)$, "unavailability of recommended inputs in time" reported by (29.33\%), "lack of technical guidelines" reported by $(24.00 \%)$ and "high losses during marketing" reported by $(22.67 \%)$ respectively. 
Table.1 Economics of different mixed farming modules per farm in respect of per hectare. (Rs. /farm per year)

\begin{tabular}{|c|c|c|c|c|c|}
\hline \multirow{2}{*}{$\begin{array}{l}\text { Economic } \\
\text { Viability }\end{array}$} & \multirow[t]{2}{*}{ Modules } & \multicolumn{4}{|c|}{ Size group } \\
\hline & & Small & Medium & Large & Average \\
\hline \multirow{2}{*}{$\begin{array}{c}\text { Cost of } \\
\text { production }\end{array}$} & $*$ Bajra + Mustard +2 milch animals & 67952 & 67065 & 69061 & 68025 \\
\hline & $\begin{array}{c}* * \text { Bajra }+ \text { wheat }+ \text { gram }+2 \text { milch } \\
\text { animals }\end{array}$ & 73221 & 73239 & 74906 & 73788 \\
\hline \multirow[t]{2}{*}{ Net income } & $*$ Bajra + Mustard +2 milch animals & 84463 & 86498 & 79176 & 83380 \\
\hline & $\begin{array}{c}* * \text { Bajra }+ \text { wheat }+ \text { gram }+2 \text { milch } \\
\text { animals }\end{array}$ & 85078 & 86247 & 80869 & 84066 \\
\hline \multirow[t]{2}{*}{ B.C. Ratio } & $*$ Bajra + Mustard +2 milch animals & 2.37 & 2.45 & 2.28 & 2.36 \\
\hline & $\begin{array}{c}* * \text { Bajra }+ \text { wheat }+ \text { gram }+2 \text { milch } \\
\text { animals }\end{array}$ & 2.32 & 2.39 & 2.24 & 2.31 \\
\hline \multirow{2}{*}{$\begin{array}{l}\text { Diversification } \\
\text { Index }\end{array}$} & Farming system I & 0.53 & 0.56 & 0.55 & 0.55 \\
\hline & Farming system II & 0.53 & 0.56 & 0.54 & 0.54 \\
\hline
\end{tabular}

*Rainfed farming system $=$ bajra (kharif) + mustard (rabi) +2 milch animals

$* *$ Irrigated farming system $=$ bajra $($ kharif $)+$ wheat + gram $($ rabi $)+2$ milch animals

Table.2 Constraints in different farming systems in study area $(\mathrm{n}=75)$

\begin{tabular}{|c|l|c|c|}
\hline $\begin{array}{c}\text { S. } \\
\text { No }\end{array}$ & \multicolumn{1}{|c|}{ Particulars of constraints } & frequency & $\begin{array}{c}\text { \% to } \\
\text { total }\end{array}$ \\
\hline $\mathbf{1}$ & Unfavourable climatic condition & 36 & $\mathbf{4 8 . 0 0}$ \\
\hline $\mathbf{2}$ & Uncertain of rainfall & $56^{*}$ & $\mathbf{7 4 . 6 7}$ \\
\hline $\mathbf{3}$ & High infestation of disease and pest & $42^{*}$ & $\mathbf{5 6 . 0 0}$ \\
\hline $\mathbf{4}$ & Shortage of labour at peak period & $55^{*}$ & $\mathbf{7 3 . 3 3}$ \\
\hline $\mathbf{5}$ & Lack of proper management of family labour & 25 & $\mathbf{3 3 . 3 3}$ \\
\hline $\mathbf{6}$ & Scarcity of owned funds & $49^{*}$ & $\mathbf{6 5 . 3 3}$ \\
\hline $\mathbf{7}$ & Unavailability of recommended inputs in time & 22 & $\mathbf{2 9 . 3 3}$ \\
\hline $\mathbf{8}$ & Lack of knowledge improved technology & 30 & $\mathbf{4 0 . 0 0}$ \\
\hline $\mathbf{9}$ & Lack of technical guidelines & 18 & $\mathbf{2 4 . 0 0}$ \\
\hline $\mathbf{1 0}$ & High cost of inputs and improved technology & $60^{*}$ & $\mathbf{8 0 . 0 0}$ \\
\hline $\mathbf{1 1}$ & Lack of timely supply of inputs & 37 & $\mathbf{4 9 . 3 3}$ \\
\hline $\mathbf{1 2}$ & Lack of credit availability & 26 & $\mathbf{3 4 . 6 7}$ \\
\hline $\mathbf{1 3}$ & Lack of proper marketing system & 24 & $\mathbf{3 2 . 0 0}$ \\
\hline $\mathbf{1 4}$ & Unavailability of marketing loan & $57^{*}$ & $\mathbf{7 6 . 0 0}$ \\
\hline $\mathbf{1 5}$ & Low price for the produce & $62^{*}$ & $\mathbf{8 2 . 6 7}$ \\
\hline $\mathbf{1 6}$ & Lack of storage facility & 23 & $\mathbf{3 0 . 6 7}$ \\
\hline $\mathbf{1 7}$ & High transportation charges & 27 & $\mathbf{3 6 . 0 0}$ \\
\hline $\mathbf{1 8}$ & High losses during marketing & 17 & $\mathbf{2 2 . 6 7}$ \\
\hline & Average score & $\mathbf{3 7}$ & $\mathbf{4 9 . 3 3}$ \\
\hline
\end{tabular}


The study revealed that the data among two combinations i.e. rainfed farming system (crop production +2 milch animals) and irrigated farming system (crop production +2 milch animals), Farming system II gave higher net income in respect of increase total return over enterprise and feed and fodder for milch animal and additional employment for family labour. Hence, it implies (crop production +2 milch animals) in irrigated situation was the best crop and livestock combination for favorable income and enterprise. The diversification index for both the farming system was carried out to determine the importance of livestock system in different farming system.

The diversification index for farming system for different size of holding and for all farms as a whole clearly indicates that crop + livestock system found to suitable among both the rainfed and irrigated farming system because diversification index for both the farming system found to less than one. This low and approximate similar diversification index shows that no farming system can be shifted in each other because there is no any chance of increasing the irrigation facilities in study area.

\section{References}

Anonymous (2008). Farming Systems. DARE/ICAR, New Delhi: Annual Report.

Arjun Prasad and Sam, M.J. (1990). Multiple cropping in Tungabhadra dam region of Karnataka. Annals of Agricultural Research. 11(2):149-154.
Bhole, B. D.; Deshpande, S. L. and Mabale, Y.P. (1984). An economic analysis of dry farming technology in selected area of Akola district, Department of Agricultural Economics and Statistics, Punjab Rao Krishividyapeeth, Akola

Chan,G.L. (2003).What does Integrated farming system do? Environmental Management Consultancy. Place of publication, type of publication?

Govardhan,R. (1998). An economic analysis of cropping system in left bank canal command area of Tungabhadra ProjectKarnataka. M.Sc. (Agri.) Thesis, University of Agricultural Sciences, Dharwad.

Jha, Dayanatha (2003). An overview of farming systems research in India. Ann.Agric.Res.New Series. 24(4):695706.

Koshta,A.K.; Chandrakar, M.R. and Agrawal, K.G. (1996). An economic study of milch stock breeds in Raipur district of Madhya Pradesh. Indian.J. Dairy.Sci. 49(5):314-322.

Singh,A. and Singh,R.V. (1977). Impact of Dairy Enterprise on productivity and employment. Agril. Situa. India. 32(3):139-142.

Sitaramaswamy,J. and Jain,D.K. (1993). The role and type of models in farming systems research. World Agril Econ. and Rural Socio. (37): 150-214.

Yadav,M. (2013).An evaluation of optimum and profitable combination of croplivestock enterprise in Khargone block of Khargone district Madhya Pradesh.M.Sc (Agri,) Thesis submitted to R.V.S.K.V.V. Gwalior.

\section{How to cite this article:}

Suman. D. S., G. Bihare, G. S. Patel, P. K. Patel and Raghywanshi. J. S. 2020. To Study the Economic Viability of Different Farming System in Bhind District of Madhya Pradesh, India. Int.J.Curr.Microbiol.App.Sci. 9(06): 1533-1537. doi: https://doi.org/10.20546/ijcmas.2020.906.189 